\title{
The impact of sports on above-the-average and high-performing students' achievements in Hungarian and Romanian higher education institutions
}

\author{
Klára Kovács
}

Researcher, PhD-student, Center for Higher Education Research and Development, Hungary, University of Debrecen, 4032 Debrecen, Egyetem sqr. 1.

E-mail: kovacs.klarika87@gmail.com

\begin{abstract}
In this paper, we apply such a complex indicator of student achievement to study the effect of sporting habits on higher education students' achievement in Romania and Hungary in the Partium region. We created a complex indicator based on 12 dimensions and re-coded the index to a binominal variable: measuring above-the-average and high-performing student achievement. Consequently, our main research question is whether sporting habits contribute to becoming a member of the above-the-average or high-performing student groups. In our analysis, we control for the effect of social background variables and examine also the effects of subjective wellbeing (happiness and life satisfaction), selfassessment on health and resilience (mental fitness, flexibility, adaptability to changed conditions) as the positive influence of these latter factors on student achievement has been verified by others and our previous studies as well.

In the frame of our research, Higher Education for Social Cohesion Cooperative Research and Development in a Crossborder Area (HERD, HURO/0901/253/2.2.2.) a survey was carried out in the three countries of the Partium region (Hungary, Romania, Ukraine). The Ukrainian subsample was eliminated from the current analysis due to low headcounts and biased effects, thus our database included 2619 students. According to our results free-time sporting, subjective health status and resilience increase the likelihood to belong to the above-the-average group, while the two regular forms of sporting and mental fitness promote students to belong to the high-performing group. The level of subjective well-being decreases the likelihood to belong to both student groups. These support the assumption that sporting students are more engaged towards their studies and work as well and consider their studies as more meaningful. Such an attitude serves as a motivational factor for finishing their studies even more successfully, continuing their studies even at the doctoral level. These positive personality traits, values and attitudes that are also related to sporting define advantages in academic and personal lives and the labour market through the transfer-effect of sports.
\end{abstract}

\section{Indexing terms/Keywords}

Sporting habits; academic achievement; Higher Education; Subjective well-being; Resilience

\section{Academic Discipline And Sub-Disciplines}

Education, Sociology, Sport Science

\section{SUBJECT CLASSIFICATION}

Academic Achievement in Higher Education

\section{TYPE (METHOD/APPROACH)}

Survey; Chi-squared test; Variance analyze; Logistic regression

\section{Council for Innovative Research}

Peer Review Research Publishing System

\section{Journal: Journal of Social Sciences Research}

Vol. 5, No.3

Jssreditor.cir@gmail.com

www.jssronline.com 


\section{INTRODUCTION}

Both international and Hungarian studies on student achievement have been extensive: the topic is relevant from the perspectives of education policy, the economics of education and the entire country (serving as a tool of measuring economic productivity) and the sociology of education as well measuring social mobility. Most studies consider student achievement as scores of standardised tests measuring some sort of skills, abilities and knowledge, while researchers emphasizing the complex nature of achievement denote such interpretations too narrow and thus apply soft, subjective indicators of student achievement. Pusztai [1] [2] sets an example of such examination when studying higher education students' achievement in the Partium region when she applied the following indicators: (a) high esteem of schooling, (b) entrance to higher education, willingness to study further (Masters level and beyond), (c) the planned duration of higher education studies, (d) extra study work (language exam, study competitions, publications, Students' Scholarly Circle ${ }^{1}$ participation), (e) work attitudes, work values, (f) students' productive contribution to their self-education, (g) moral judgement ability, (h) grade point average, (i) students' perception of lecturer reward.

In the present paper we apply such a complex indicator of student achievement to study the effect of sporting habits on higher education students' achievement in Romania and Hungary in the Partium region. We created a complex indicator based on 12 dimensions and re-coded the index to a binominal variable: measuring above-the-average and highperforming student achievement. Consequently, our main research question is whether sporting habits contribute to becoming a member of the above-the-average or high-performing student groups. In our analysis, we control for the effect of social background variables and examine also the effects of subjective wellbeing (happiness and life satisfaction), selfassessment on health and resilience (mental fitness, flexibility, adaptability to changed conditions) as the positive influence of these latter factors on student achievement has been verified by others and our previous studies as well [3] [4] [5] [6], for the influence of sports on these factors see [7] [8] [9].

In the frame of our research, Higher Education for Social Cohesion Cooperative Research and Development in a Crossborder Area (HERD, HURO/0901/253/2.2.2.) a survey was carried out in the three countries of the Partium region by the coordination of CHERD-Hungary, Partium Christian University and the University of Oradea. The paper-based questionnaires were filled by 2728 students from the higher education institutions of three countries from the historical Partium region (Hungary, Romania, Ukraine) March-June 2012. The language of data collection was Hungarian and Romanian (see further details on the research projects and findings in the research volumes) ${ }^{2}$.

The Ukrainian subsample was eliminated from the current analysis due to low headcounts and biased effects, thus our database included 2619 students. We ensured data representative per faculties, years and levels of education by weighing.

The first part of the paper includes the theoretical framework on previous research involving sporting habits and student achievement, then our research questions, variables and research methods are detailed, which are followed by the description of our research results.

\section{THE IMPACT OF SPORTS ON STUDENT ACHIEVEMENT}

Research results on the correlation of sports and student achievement are not consistent (especially in the case of uppersecondary school and higher education students): some found positive [10] [11] [12], others found negative [13] [14] influence of sports, while a third set of research results have not identified any correlation of the two [15] [16].

The positive effect of sports, regular physical activities have been associated with personality development. According to the personality development theory, sports develop personality by teaching to respect hard work, perseverance, improving a number of skills, self-confidence, maturity, social competences, increasing school participation, students' educational and other performance, thus contributing to students' school achievement [17] [18] [19]. This is especially true if students would like to participate at college sports [20]. Besides, sports strengthened social relations among students, teachers, parents and schools, thus increased athletes' social capital, which also had a positive impact on their achievement. However, we should also note that the different sports and sporting forms have diverse influence on the various dimensions of academic achievement [17]. Consequently, it is important to define sporting habits as a multi-dimensional concept and apply this complex concept for analysing the different dimensions of achievement [12].

Those research results that did not find significant correlation between sporting and academic achievement [20] [15] [16] support Coleman's social capital theory [21]. According to Coleman, extracurricular activities, such as sports, contribute to the acceptance of sporting youths, the establishment of their roles and authority among their peers and as a result of the popularity of sports, they build stronger relations with their teachers and parents. Consequently, their social capital increases, which impacts their educational achievement positively. This culminates in a so-called zero-sum situation as sporting consumes energy from learning, what is more, schools emphasize their athletes' achievements and partly consider those as their success, thus by highlighting sports and sport achievements they also contribute to the worsening of academic achievement [20] [18]. As a result, they lose the benefit of social prestige, recognition and capital or the scale might move to the negative dimension and athletes perform worse at schools. This is also supported by Hauser and Lueptow's research [22]. According to them, sporting secondary school students had better academic achievement by the

\footnotetext{
1 Students' Scholarly Circle means a scientific competition for students in Hungary, where students have to write a publication related to their disciplinary area and present it, if it is chosen by scientific committee.

${ }^{2}$ http://unideb.mskszmsz.hu/en/final-products
} 
end of secondary schooling but their development was smaller (measured in points) than their non-sporting fellows, thus their performance relatively decreased.

Coleman's social capital theory is utilised in a different way in the world of college sports. While sporting secondary school students have high prestige among peers and teachers due to their sport achievements, and their popularity helps them to build social relations both inside and outside of schools, their relations are limited to their sports communities in higher education, which delimits them from other communities, thus sporting decreases students' social capital. A well-known expression for this situation is "dumb jock" [23].

Further causes for the negative or neutral impact of sports are constituted by the influential power of social background variables on achievement factors. Due to social background, a sort-of self-selection process occurs in high school and college sports, which raises the question whether socially better-off students start to sport and are these students the same as those who perform better on standardized tests due to their better social status and thus get selected for higher education studies and obtain degrees. Research results confirmed that talented but disadvantaged athletes (for example, Afro-Americans) that study at universities/colleges with sport scholarships might perform worse academically due to their disadvantaged situation (in many cases this begins at secondary schools) [20] [24] [16] [12] [25] [26]. Purdy et. al. [13] found the same: they had researched more than 2000 college/university athletes for 10 years and found that athletes were less prepared and performed worse academically than their non-sporting peers. Not all athletes performed at the same level: students with football and basketball scholarships, Afro-Americans and participants in paid sports performed the worst. Besides, the phenomenon is more complicated as a longitudinal research project examining university/college athletes in the entire USA for decades found that among lead athlete university students, the ratio of disadvantaged students is not higher, what is more, they are more likely to have beneficial social status and still, they perform worse than their non-sporting peers and are more likely to belong to the student groups with the worst achievement [27]. As a result, we have to control for social background variables when examining sports and student achievement.

In the continuation of Shulman, Bowen's research [27] Bowen and Levin [23] researched athletes, coaches, sports and university leaders from the different sports organizations of 32 higher education institutions with quantitative and qualitative methods. They differentiated recruited athletes that are selected by coaches from competitive athletes that belong to lower-level leagues and participate at competitions from free will (walk-ons) and compared them based on various criteria (for example, achievement indicators) to non-sporting peers and female athletes. Their results show that non-sporting students had the best achievements while elite male athletes, members of the highest level university sport leagues and the most popular American sports (American football, ice hockey, basketball, gymnastics) performed the worst academically. Among the latter, the ratio of those that belonged to the worst performing one-third within their own groups was the highest. This is partly explained by the fact that these athletes performed worse at secondary schools already but coaches select them to recruited athlete teams for their extraordinary sport achievements, which worsen their achievement in higher education due to their sports obligations. Another explanation is that recruited athletes are more likely to come from disadvantaged background but this was not confirmed, recruited and competitive athletes are characterized by similar social background but received social aid and compensations for social disadvantages from universities to a larger extent than their non-sporting peers. This also verifies inequalities in social background but we have to note that such a measurement and interpretation of social status is extremely narrow. All of these results support the importance of the simultaneous examination of the different forms of sporting and social background related to achievement indicators.

\section{RESEARCH QUESTIONS, METHODS}

In our research, we aim to find the answer to how different sporting activities influence students' academic achievement. Is this influence positive based on the personality development model so that students perform above the average or higher academically? Or the contrary: is Coleman's social capital theory verified among university students, thus the level of social capital is lower due to limited social relations (to sporting peers), which negatively impacts academic achievement? Furthermore, it is also important to track how this pattern changes if we control for social background variables and also, the variables for subjective well-being, resilience and self-assessed health status. If the answer is yes, do we still see the effect of sporting habits?

The analysis was performed on the 2012 HERD database. The population included all full-time first and final year students of all levels of education in the following higher education institutions: The University of Debrecen (Hungary), Three faculties of College of Nyíregyháza (Hungary), Kölcsey Ferenc Teacher Training Institute of Debrecen Reformed Theological University (Hungary), Ferenc Rákóczi II . Transcarpathian Hungarian Teacher Training College (Berehove, Ukraine), Faculty of Humanities and Natural Sciences with the Hungarian Language of Education of Uzhgorod National University (Ukraine), The Satu Mare (Romania) branch of Babeş-Bolyai University. The survey was anonym and voluntary. The sample involved $9 \%$ of the $1^{\text {st }}$ and $3^{\text {rd }}$ year Bachelor population and the undivided programs and $20 \%$ of the $1^{\text {st }}$ and $4^{\text {th }}$ year Master and undivided study programs. The above sample was complimented by three sub-samples from the University of Oradea (Romania), Emanuel University in Oradea (Romania) and the Partium Christian University. We excluded the Ukrainian sub-sample from the analysis, thus the final headcount is 2619.

To identify sporting habits, we examined different variables. We defined student groups with cluster analysis based on the frequency of sporting, attitudes to the importance of sporting and whether students institutionally participated in competitive sports. We measured subjective well-being with an index of happiness and satisfaction of life (0-100 points) based on EVS and our previous research results [5] [6]. We applied a standardized measurement tool of residence (0-100 point) and the question of whether respondents felt healthy for subjective health status ( 0 no, 1 yes). Among the most 
important social background variables, we included the following: country ( 0 Romania, 1 Hungary), sex ( 0 female, 1 male); economic capital: objective financial status (depending on the number of possessed items 0-16 point), subjective financial status (a scale for measuring it as compared to other families in the country 0-10 point); cultural capital: parents' education level measured in the number of finished classes, type of residence ( 0 village, 1 city).

To measure student achievement we created a complex variable based on Pusztai's works [28] [1] [2] from six components. Each component involved complex content and each respondent could obtain 0-12 points. Components are weighed internally due to their different content ${ }^{3}$. The components are listed below.

1. Perseverance for continuing education and educational goals: 1 . studies suspended previously $(0-11$, recoded in the index: 0-no, 1-yes), 2. confidence in the meaningfulness of studies (0-4, recoded in the index: 0-no, 1-yes), 3. ability to finish undertaken tasks (0-5, recoded in the index: 0-no, 1-yes).

2. Extracurricular activities and commitment to these: for example, Students' Scholarly Circle thesis, publications, conference presentations, curriculum vitae in native language and in English, foreign language exams $(0-13$, recoded in the index: 0-not committed, 1-committed).

3. Intensity of studying: 1. class attendance, 2. academic activity in and outside of classes, 3. preparation to classes, 4. Ratio of successful exams (compared to faculty average, above the average 1 point, below the average 0 point).

4. Student conduct according to academic norms $(-53-4$, recoded in the index: above the sample average 1 point, below the sample average 0 point).

5. Affinity and willingness to work: being employed during university studies independent of the place or duration of employment (0-8, recoded in the index: above the sample average 1 , below the sample average 0$)$.

6. Willingness to continue education and self-education: another major, $\mathrm{PhD}$, Bachelor or Master programs, separate points for doctoral plans and postgraduate studies (0-3 point).

We created an achievement index based on these complex dichotomous variables, besides, we defined another dichotomous set: a variable for above-the-average and another for the highest one-third, high-performing students. With the help of logistic regression we examined whether the different forms of sporting, subjective well-being, resilience, selfassessed health status and the most important social background variables impact the likelihood to belong to the abovethe-average and high-performing student groups, and if yes, to what extent and how.

\section{RESEARCH RESULTS}

The highest ratio, $26.2 \%$ of students exercise weekly, $17 \%$ more frequently but it is seriously worrying that one-quarter of them never or almost never (annually) do physical activities. The importance of sporting serving as a motivational factor revealed three groups via factor analysis: 1. Experience-centred, mental fitness orientation, 2. Competitive-community type, 3. Health care attitude [29]. We identified three athlete types among sporting students based on the above attitudes, the frequency of sporting and the elite sport nature of sporting activities: 1. Competitive athletes (16.5\%), 2. Regular freetime sporting students $(43,8 \%), 3$. Occasional, social-community-focused sporting $(11,2 \%)$ and non-sporting students (28.4\%).

The average level of students' mental fitness is 68 , their subjective well-being is 71 on a scale ranging from $0-100$, and only half of the university students felt themselves healthy. If we examine the two dimensions of subjective well-being separately we find that students rather feel satisfied with their lives (56.8\%) and happy (60\%) [9] .

The mean values of separate achievement components and the complex achievement index are listed in Table 1.

Table 1: The means of achievement components and the complex achievement index among students (N=2619) (scores). Source: HERD 2012

\begin{tabular}{|l|c|}
\hline Number of studies suspended (0-10) & 0.08 \\
\hline Meaningful studies (0-4) & 3.36 \\
\hline Ability to finish undertaken tasks (0-5) & 3.75 \\
\hline Commitment to educational and extracurricular activities (0-13) & 4.82 \\
\hline Intensity of studying as compared to the faculty average (0-1) & 0.45 \\
\hline Class attendance as compared to the faculty average (0-1) & 0.35 \\
\hline Exam efficiency as compared to the faculty average (0-1) & 0.41 \\
\hline Intensity of preparation to classes per day as compared to the faculty average $(0-1)$ & 0.38 \\
\hline
\end{tabular}

\footnotetext{
${ }^{3}$ We created the complex variable of achievement with Gabriella Pusztai and the authors of a symposium lead by her at the 13rd National Conference of Educational Sciences used that complex variable in their presentations.
} 


\begin{tabular}{|l|c|}
\hline Student conduct based on academic norms (-53-4) & -14.5 \\
\hline Affinity to work (0-8) & 2.18 \\
\hline Willingness to continue education (0-3) & 1.07 \\
\hline Complex achievement index (0-12) & 5.26 \\
\hline
\end{tabular}

\section{The impact of sporting habits, mental fitness, subjective wellbeing and self-assessed health status on above-the-average and high-achieving students}

We examined the difference among groups defined by sporting habits in relation to the various dimensions of academic achievement in a previous paper [6]. We found significant difference among sporting groups for all the components and the complex achievement index except for the number of studies suspended, exam efficiency as compared to faculty average and the mean of daily class preparation. Competitive and free-time sporting students got the highest points with the exception of two dimensions, which supports the assumption that regular sport activities contribute to students academic achievement, thus verifying the personality development theory. Further evidence is provided by the fact that non-sporting students has the worst results in the significantly different variables except for the attitudes to academic norms. Besides, these non-sporting students had the lowest point on the complex achievement index (Table 2).

Table 2: The mean values of the achievement components and the complex achievement index in the students groups based on sporting habits ( $\mathrm{N}=2619)$. Source: HERD 2012 (Kovács 2014b)

\begin{tabular}{|c|c|c|c|c|}
\hline & $\begin{array}{l}\text { Competitive } \\
\text { athletes }\end{array}$ & $\begin{array}{l}\text { Non- } \\
\text { sporting } \\
\text { students }\end{array}$ & $\begin{array}{l}\text { Regular free- } \\
\text { time sporting } \\
\text { students }\end{array}$ & $\begin{array}{l}\text { Occasional, social- } \\
\text { community-focused } \\
\text { sporting students }\end{array}$ \\
\hline $\begin{array}{l}\text { Number of studies suspended (0- } \\
10)\end{array}$ & 0.09 & 0.07 & 0.09 & 0.05 \\
\hline Meaningful studies (0-4) & 3.39 & 3.17 & 3.45 & 3.4 \\
\hline $\begin{array}{l}\text { Ability to finish undertaken tasks } \\
(0-5)^{\star}\end{array}$ & 3.8 & 3.5 & 3.85 & 3.9 \\
\hline $\begin{array}{l}\text { Commitment to educational and } \\
\text { extracurricular activities }(0-13)^{\star}\end{array}$ & 3.2 & 2.68 & 3.12 & 3.12 \\
\hline $\begin{array}{l}\text { Intensity of studying as } \\
\text { compared to the faculty average } \\
(0-1)^{\star}\end{array}$ & 0.46 & 0.41 & 0.48 & 0.46 \\
\hline $\begin{array}{l}\text { Class attendance as compared } \\
\text { to the faculty average }(0-1)^{*}\end{array}$ & 0.37 & 0.33 & 0.34 & 0.43 \\
\hline $\begin{array}{l}\text { Exam efficiency as compared to } \\
\text { the faculty average }(0-1)\end{array}$ & 0.46 & 0.39 & 0.4 & 0.42 \\
\hline $\begin{array}{l}\text { Intensity of preparation to } \\
\text { classes per day as compared to } \\
\text { the faculty average }(0-1)\end{array}$ & 0.35 & 0.38 & 0.39 & 0.38 \\
\hline $\begin{array}{l}\text { Student conduct based on } \\
\text { academic norms }(-53-4)^{\star}\end{array}$ & -17.25 & -14.07 & -13.07 & -17.13 \\
\hline Affinity to work $(0-8)^{*}$ & 2.69 & 1.84 & 2.22 & 2.15 \\
\hline $\begin{array}{l}\text { Willingness to continue } \\
\text { education }(0-3)^{\star}\end{array}$ & 1.16 & 0.92 & 1.11 & 1.13 \\
\hline $\begin{array}{l}\text { Complex achievement index } \\
(0-12)^{\star}\end{array}$ & 5.46 & 4.78 & 5.45 & 5.38 \\
\hline
\end{tabular}

${ }^{*} \mathrm{p}<0.05$

We examined the social and other factors that impact the complex achievement index with linear regression. Among these, mental flexibility had the biggest impact and what is even more important from the perspective of our research topic, the second biggest impact was made by free-time sporting habits. Besides, competitive sports had also had positive effect when controlling for the influence of social background variables. However, it is a surprising outcome that subjective well-being had a negative effect on academic achievement (Kovács 2014b).

Furthermore, we also examined the effect of social background variables, sporting habits, subjective well-being, mental fitness and self-assessed health status on the likelihood for students to belong to the above-the-average or high- 
performing student groups. Women double the number of men in both the above-the-average or high-performing student groups, which supports women's better academic performance. In the former case, we found more urban, healthy (selfassessed), better off students in terms of subjective well-being. Better social status and resilience had a significant influential power in both student groups: these students have higher cultural and (objective) economic capital than their below-the-average or non-high-performing peers, which again supports the sustainment of inequalities between disadvantaged and non-disadvantage students in higher education study academic careers.

The bests students have an advantage in terms of mental flexibility as well: they feel stronger that they are able to perform well despite challenges - and they do perform better indeed -, they can overcome barriers and cope with everyday problems, which do not prevent them from successfully conducting their studies (Table 3 and 4).

Table 3: The distribution of social background variables and self-assessed health status in the abovethe-average and high-performing student groups (\%). Source: HERD 2012

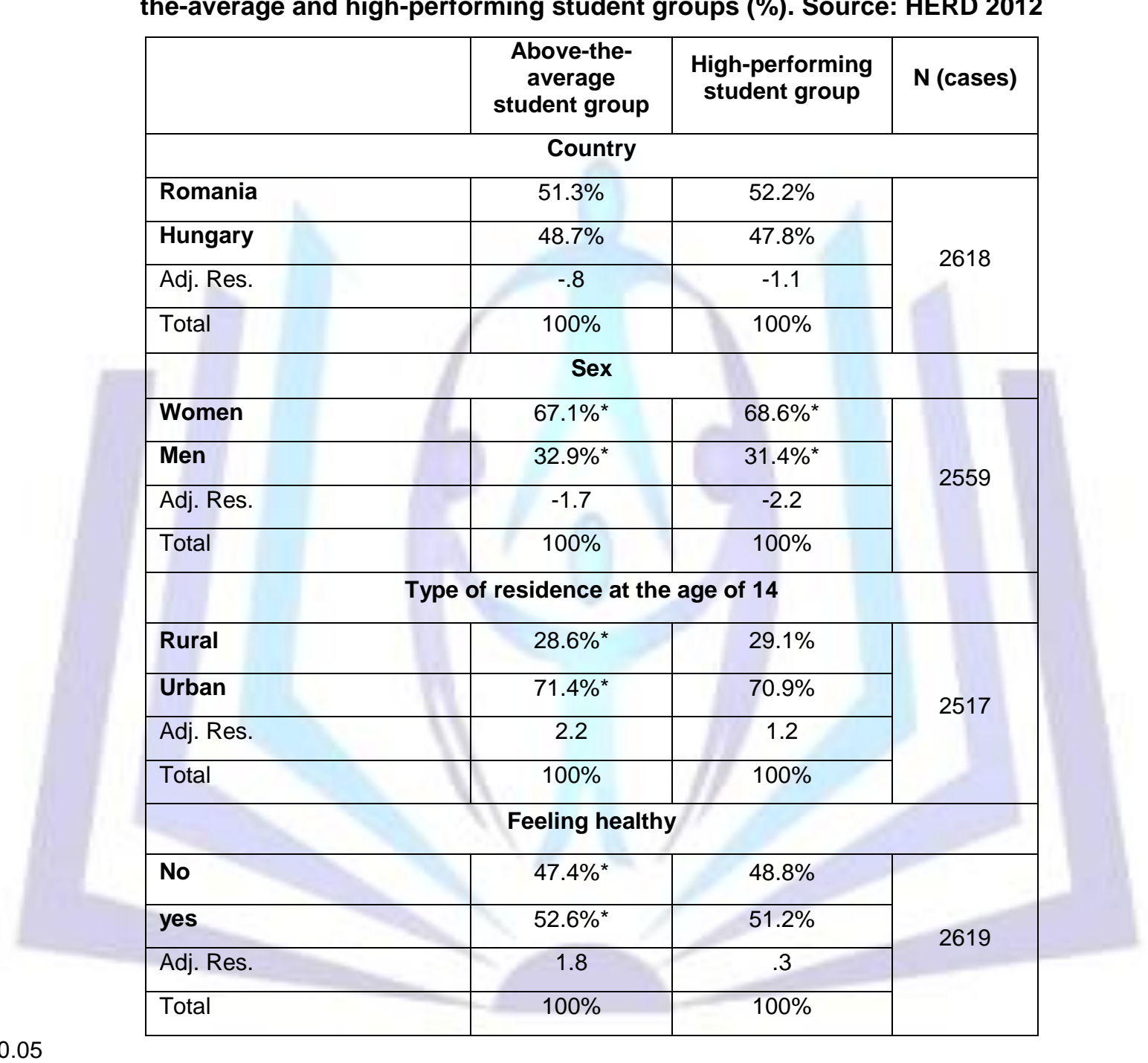

${ }^{*} \mathrm{p} \leq 0.05$

Table 4: The mean scores of parents' level of education, subjective and objective financial status, resilience and subjective well-being in the above-the-average, below-the-average, high-performing, non-high performing student groups (scores). Source: HERD 2012

\begin{tabular}{|c|c|c|c|c|c|}
\hline & $\begin{array}{c}\text { Below-the- } \\
\text { average student } \\
\text { group }\end{array}$ & $\begin{array}{c}\text { Above-the- } \\
\text { average student } \\
\text { group }\end{array}$ & $\begin{array}{c}\text { Non-high- } \\
\text { performing student } \\
\text { group }\end{array}$ & $\begin{array}{l}\text { High-performing } \\
\text { student group }\end{array}$ & $\mathbf{N}$ \\
\hline $\begin{array}{l}\text { Parents' level of education } \\
\text { in the number of classes } \\
\text { finished }\end{array}$ & $12.7^{*}$ & $12.9^{*}$ & $12.7^{*}$ & $13^{*}$ & 2449 \\
\hline $\begin{array}{l}\text { Subjective financial status } \\
\text { (0-100 scores) }\end{array}$ & $55.2^{*}$ & $56.6^{*}$ & 55.5 & 56.6 & 2449 \\
\hline
\end{tabular}




\begin{tabular}{|c|c|c|c|c|c|}
\hline $\begin{array}{l}\text { Objective financial status } \\
\text { (0-11 scores) }\end{array}$ & $4.9^{*}$ & $5.1^{*}$ & $4.9^{*}$ & $5.2^{*}$ & 1651 \\
\hline resilience (0-100 scores) & $65.4^{*}$ & $72.7^{*}$ & $66.8^{*}$ & $74^{*}$ & 2483 \\
\hline $\begin{array}{l}\text { Subjective well-being (0- } \\
100 \text { scores) }\end{array}$ & 70.3 & 71.8 & 70 & 71.7 & 2348 \\
\hline
\end{tabular}

${ }^{*} \mathrm{p} \leq 0.05$

We examined the likelihood to belong to these two groups with linear regression (Table 5). The outcomes of the logistic regression models show that only free-time sporting habits has a significantly positive effect while controlling for mental fitness, self-assessed health status, subjective well-being and social background variables: free-timer sporting students have 1.5 higher chance to belong to the above-the-average group than their non-sporting peers. The higher the level of mental fitness is, the higher the likelihood is to belong to this group, besides, students who feel healthy have 1.3 higher likelihood to belong to this group. Similarly to the results of the complex achievement index, we identified the negative effect of subjective well-being in this case as well: the higher subjective well-being is, the smaller the likelihood is to belong to the above-the-average student group. Of social background variables, only parents' level of education had an effect which is positive -, the higher their level of education is, the higher the likelihood for students to belong to this group.

By examining the likelihood to belong to the -high-performing student group we found that both competitive athletes and free-time sporting students have a higher chance to belong to this group. Although the effect of competitive sports ceased with the involvement of resilience, self-assessed health status and subjective wellbeing, by controlling for social background variables we could detect its significant positive again. Competitive athletes had a 1.5, free-time sporting students had a 1.3 higher chance to belong to this group than their non-sporting fellows. Resilience had also a positive effect, the more students feel resilient against stress, negative life events, the higher their chance is to become highperforming students. Of social background variables only sex had an impact: male students had 0.7 less chance to belong to this group. We can also detect the negative impact of subjective well-being in this case: the higher the level is, the smaller the likelihood is to belong to this group.

Table 5: Likelihood to belong to the above-the-average and high-performing student groups

(Exponential B regression coefficients). Source: HERD 2012

\begin{tabular}{|c|c|c|c|c|c|c|}
\hline & \multicolumn{3}{|c|}{$\begin{array}{c}\text { Dependent variable: likelihood of } \\
\text { belonging to the above-the-average } \\
\text { student group }\end{array}$} & \multicolumn{3}{|c|}{$\begin{array}{c}\text { Dependent variable: likelihood of } \\
\text { belonging to the high-performing } \\
\text { student group }\end{array}$} \\
\hline & $\begin{array}{l}\text { Exp. B } \\
\text { 1.modell }\end{array}$ & $\begin{array}{c}\text { Exp. B } \\
\text { 2.modell }\end{array}$ & $\begin{array}{l}\text { Exp. B } \\
\text { 3.modell }\end{array}$ & $\begin{array}{c}\text { Exp. B } \\
\text { 1.modell }\end{array}$ & $\begin{array}{c}\text { Exp. B } \\
\text { 2.modell }\end{array}$ & $\begin{array}{c}\text { Exp. B } \\
\text { 3.modell }\end{array}$ \\
\hline $\begin{array}{c}\text { Experience- } \\
\text { searching } \\
\text { competitive sporting }\end{array}$ & $1.829^{*}$ & 1.448 & 1.486 & $1.815^{\star}$ & 1.456 & $1.550^{*}$ \\
\hline $\begin{array}{l}\text { Regular } \\
\text { recreational-free- } \\
\text { time sporting }\end{array}$ & $1.676^{*}$ & $1.452^{*}$ & $1.443^{*}$ & $1.557^{*}$ & $1.384^{*}$ & $1.367^{\star}$ \\
\hline $\begin{array}{l}\text { Occasional, social- } \\
\text { community-focused } \\
\text { sporting }\end{array}$ & 1.437 & 1.263 & 1.275 & 1.338 & 1.153 & 1.187 \\
\hline Resilience (0-100) & & $1.029^{*}$ & $1.030^{*}$ & & $1.028^{*}$ & $1.030^{*}$ \\
\hline $\begin{array}{l}\text { Self-assessed } \\
\text { health status }\end{array}$ & & 1.280 & $1.327^{*}$ & & 1.115 & 1.132 \\
\hline $\begin{array}{l}\text { Subjective well- } \\
\text { being }(0-100)\end{array}$ & & $.993^{*}$ & $.992^{*}$ & & $.991^{*}$ & $.990^{*}$ \\
\hline $\begin{array}{c}\text { Sex }(0 \text { - women, } 1 \text { - } \\
\text { men })\end{array}$ & & & .800 & & & $.731^{*}$ \\
\hline $\begin{array}{l}\text { Country (Hungary } 0 \\
- \text { no, } 1-\text { yes) }\end{array}$ & & & .903 & & & .954 \\
\hline $\begin{array}{l}\text { Parents' level of } \\
\text { education }\end{array}$ & & & $1.029^{*}$ & & & 1.017 \\
\hline $\begin{array}{l}\text { Subjective financial } \\
\text { status }\end{array}$ & & & .996 & & & .989 \\
\hline
\end{tabular}




\begin{tabular}{|c|c|c|c|c|c|c|}
\hline $\begin{array}{c}\text { Objective financial } \\
\text { status }\end{array}$ & & & 1.025 & & & 1.058 \\
\hline
\end{tabular}

\section{CONCLUSIONS ${ }^{4}$}

In our analysis we aim to answer the question of how sporting habits impact students' academic achievement, which we examined with multiple methods. We constructed a complex achievement index with dichotomous values to identify above-the-average and high-performing groups. Besides sporting habits, we also analysed the impact of subjective wellbeing, mental fitness, self-assessed health status and the most important social background variables. Free-time sporting, subjective health status and resilience increase the likelihood to belong to the above-the-average group, while the two regular forms of sporting and mental fitness promote students to belong to the high-performing group. The level of subjective well-being decreases the likelihood to belong to both student groups. These support the assumption that sporting students are more engaged towards their studies and work as well and consider their studies as more meaningful. Such an attitude serves as a motivational factor for finishing their studies even more successfully, continuing their studies even at the doctoral level. These positive personality traits, values and attitudes that are also related to sporting define advantages in academic and personal lives and the labour market through the transfer-effect of sports. Besides, students can also benefit from these advantages in the world of sports, too, which might lead up to an easier life after university studies, thus regular sporting habits make students happier and more satisfied directly and directly through better academic achievement factors.

Numerous authors argued for the exemplary sports life of USA and UK universities as in those countries, the values, efficiency and quality of higher education institutions are measured by both academic and sports performance [30] [31]. The sports teams and their success might influence students and parents' institution choice and students' future. The strong relation of sports and higher education systems is also shown by the fact that some high school students - in many cases coming from disadvantaged background - win scholarships to continue their education because of their notable sports achievements. However, US college sports is highly criticised because of its dependence on economics and the media, selling recruited athletes, causing worse academic achievement and personal conduct (behaviour, deviance) problems among them. We can state that college sports in the examined Hungary-Romania cross-border region differs significantly from this in there is no high place for sports in higher education institutions' image, students do sport less regularly (only $17 \%$ sports three time a week, $26 \%$ sports once or twice a week) and also, sporting has a different impact on students' academic career. Although less students do sport regularly, especially at the competitive level but contrary to their American peers, they are more successful academically, in terms of commitment and efficiency than their nonsporting fellows. Coleman's theory on the positive effect of social capital on achievement seems to be verified among our sporting student groups contrary to US competitive athletes: our sporting students are open, participate in more extracurricular activities, thus they are members of numerous communities, committed towards these communities, their studies, work, which is not countervailed by the time spent on sports-related duties and obligations.

\section{REFERENCES}

[1] Pusztai G. 2009. A társadalmi tőke és az iskola. Új Mandátum Kiadó, Budapest

[2] Pusztai G. 2011. A láthatatlan kéztől a baráti kezekig. Új Mandátum Kiadó, Budapest

[3] Mechanic, D., Hansell, S. 1987. Adolescent Competence, Psychological Well-Being, and Self-Assessed Physical Health. Journal of Health and Social Behavior 4. 364-374.

[4] Ye, Y., Mei, W., Liu, Y. 2012. Effect of Academic Comparisons on the Subjective Well-Being of Chinese Secondary School Students. Social Behavior and Personality 8. 1233-1238.

[5] Quinn, P. D. és Duckworth, A. L. (2007): Happiness and Academic Achievement: Evidence for Reciprocal Causality.

[6] Kovács K. 2014b. A sport és az akadémiai eredményesség összefüggéseinek vizsgálata a partiumi hallgatók körében. Magyar Pedagógia. (in printing).

[7] Bălţătescu, S., Kovács, K. 2012. Sport Participation and Subjective Well-being among University Students in the Hungarian-Romanian-Ukrainian Cross-border Area. In: Pusztai, G., Hatos, A., Ceglédi, T. (eds.) Third Mission of Higher Education in a Cross-Border Region. Center for Higher Education Research and Development - Hungary, University of Debrecen, Debrecen. 134-148.

[8] Bălţătescu, S., Kovács, K. 2013. Sport and subjective well-being among Romanian and Hungarian students. The mediation of resilience and perceived health. In Zamfir, E., Maggino, F. (eds.): The European Culture for Human Rights: The Right to Happiness. Newcastle, Cambridge Scholars Publishing. 174-191.

[9] Kovács K. 2014a. Boldogító mozgás? A sportolás hatása a partiumi hallgatók szubjektív jóllétére, rezilienciájára és egészségének önértékelésére. Kapocs 2. 2-13.

\footnotetext{
${ }^{4}$ The paper is published with the help of the Institutional Effects on student achievement in Higher Education study, with the support of the University of Debrecen, research project No. RH/885/2013.
} 
[10] Hartmann, D. 2008. High School Sports Participation and Educational Attainment: Recognizing, Assessing, and Utilizing the Relationship. Report to the LA84 Foundation. LA84 Foundation.

[11] Field, T., Diego, M., Sanders, C. E. 2001. Exercise is positively related to adolescents' relationships and academics. Adolescence 36. 105-110.

[12] Castelli, D. M., Hillman, Ch. H., Buck, S. M., Erwin, H. E. 2007. Physical Fitness and Academic Achievement in Thirdand Fifth-Grade Students. Journal of Sport \& Exercise Psychology 29. 239-252.

[13] Purdy, D. A., Eitzen, S. D. és Hufnagel, R. 1982. Are Athletes also Students? The Educational Attainment of College Athletes. Social Problems, 4. 439-448.

[14] Maloney, M. T., McCormick, R. E. 1993. An Examination of the Role That Intercollegiate Athletic Participation Plays in Academic Achievement: Athletes' Feats in the Classroom. The Journal of Human Resources 3. 555-570.

[15] Fisher, M., Juszczak, L., Friedman, S. B. 1996. Sports participation in an urban high school: academic and psychologic correlates. Journal of Adolescence Health 5. 329-34.

[16] Melnick, M. J., Sabo, D. F., Vanfossen, B. 1992. Educational effects of interscholastic athletic participation on AfricanAmerican and Hispanic youth. Adolescence 27. 295-308.

[17] Brohm, B. A. 2002. Linking Extracurricular Programming to Academic Achievement: Who Benefits and Why? Sociology of Education 1. 69-95.

[18] Miller, K. E., Melnick, M. J., Barnes, G. M., Farrell, M. P., Sabo, D. 2007. Untangling the Links among Athletic Involvement, Gender, Race, and Adolescent Academic Outcomes. Social Sport Journal 2. 178-193.

[19] Rajesh, S. n. d. Sports and Academic Achievement.

[20] Eitle, McNulty, T., Eitle, D. J. 2002. Race, Cultural Capital, and the Educational Effects of Participation in Sports. Sociology of Education 2. 123-146.

[21] Coleman, J. S. (1961): The Adolescent Society. The Free Press, New York

[22] Hauser, W., Lueptow, L. 1978. Participation in athletics and academic achievement: a replication and extension. The Sociological Quarterly 19. 304-309.

[23] Bowen, W. G., Lewin, S. A. 2003. Reclaiming the Game. College Sports and Educational Values. Princeton - Oxford. Princeton University Press

[24] Eitzen, S. D., Purdy, D. A. 1986. The Academic Preparation and Achievement of Black and White Collegiate Athletes. Journal of Sport \& Social Issues 10. 15-29.

[25] Sellers, R. M. 1992. Articles Racial Differences in the Predictors for Academic Achievement of Student-Athletes in Division I Revenue Producing Sports. Sociology of Sport Journal 1. 48-59.

[26] Upthegrove, T. R., Roscigno, V. J., Zubrinsky, C. C. 1999. Big Money Collegiate Sports: Racial Concentration, Contradictory Pressures, and Academic Performance. Social Science Quarterly 4. 718-737.

[27] Shulman, J. L., Bowen, W. G. 2001. The game of life: college sports and educational values. Princeton, New Jersey, Princeton University Press

[28] Pusztai G. 2004. Iskola és közösség felekezeti középiskolások az ezredfordulón. Gondolat Kiadó, Budapest

[29] Kovács K. 2013. Bourdieu, Hradil és Bandura elméleteinek vizsgálata a sportra vonatkozóan. A társadalmi, környezeti és egyéni tényezők hatása a partiumi régió hallgatóinak sportolására. Társadalomkutatás 2. 175-193.

[30] Bács Z. 2011. A magyar sport működési szerkezetének lehetséges szegmense: a felsőoktatási sportszervezetek. Magyar Sporttudományi Szemle 3. 21-23.

[31] Leopold J. 2008. Versenytorna az amerikai egyetemeken. Magyar Sporttudományi Szemle 4. 48—49.

\section{Author' biography}

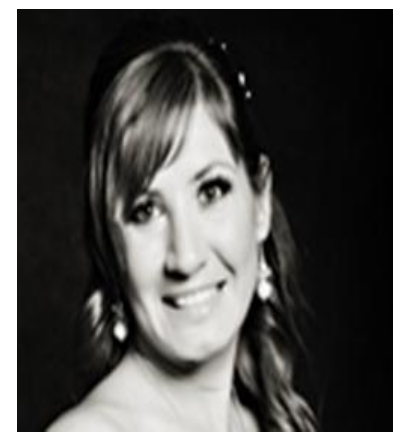

Klára Kovács is a PhD. candidate at Educational and Cultural Doctoral Program and a researcher of Center of Higher Education Research and Development Hungary (CHERD-H), University of Debrecen. The aim of her researches is to introduce and analyze sporting habits of students at the Hungarian - Romanian - Ukrainian cross-border area and to examine what are the social cultural, environmental and individual factors that affect it, whether that involves a student sport activities during his or her university studies. She examines the relationships between healthy or unhealthy behavior, subjective well-being, achievement and sport as a social protective factor: how contributes sport to students' well-being and academic and nonacademic achievement. 